The Reid case in short, must be understood to have enunciated a simple, sensible rule-Congress had directed the federal courts to follow in criminal cases the rules of evidence of the common law of 1789 . One of the essential principles of the law thus adopted as a rule of decision was the capacity to change and grow.

With this rule of the Reid case, the holdings in the Rosen and Funk cases do not conflict. They exemplify it; and reaffirm its validity. And in the light of this analysis the apparent dilemma of state statutes becoming federal common law dissolves, ${ }^{32}$ since in the process of growth the common law may be influenced by the same philosophical ideas and societal changes which lead legislatures to pass statutes abolishing disqualifications of witnesses. That the legislature reacts more quickly to the stimuli should not be considered to preempt the field and to inhibit the natural development of the common law so as to prevent it from reaching the same result. In fact it is entirely proper for the courts to consider widespread legislation as one of the best indications that societal opinion has been modified.

Thus understood the words of the court in the Funk case take on a new significance when they state:

The final question to which we are thus brought .... is the question of the power of these courts, in the complete absence of congressional legislation on the subject, to declare and effectuate upon common law principles, what is the present rule upon a given subject in the light of fundamentally altered conditions, without regard to what has previously been declared and practiced. It has been said so often as to have become axiomatic that the common law is not immutable but flexible, and by its own principles adapts itself to varying conditions.

If adhered to in its unconfused simplicity, the same principle will occasion no difficulty in years to come when further changes necessitate reconsideration of present rulés of evidence. 33

AdolPH A. RuBINSON

\title{
THE VALIDITY OF AGREEMENTS BY BANKS TO REPURCHASE SECURITIES
}

The case of Knass v. Madison \& Kedzie State Bank $k^{\mathrm{r}}$ is a typical sequel to certain banking excesses of the last decade. ${ }^{2}$ Defendant bank had sold securities to complainant, and had agreed to repurchase ${ }^{3}$ the securities at par or a slight dis-

${ }^{32}$ Supra, note 26.

${ }_{33}$ The potentialities of the Funk case can already be discerned in the recognition of its application to rules of admissibility of testimony other than those relating to competency of witnesses. Wolfle v. United States, 290 U.S. 6I7, 54 Sup. Ct. 279 (r934).

${ }^{ } 354$ IIl. 554, r88 N.E. 836 (1933).

2See Fribourg, The New York Mortgage Bond Situation, The Annalist (Dec. 22, 1933), 803; Williams, The Future of Mortgage Banking, Great Lakes Banker (Feb. 1934), 3.

3 The agreements were signed by a vice-president of defendant bank, generally without any designation of official position or descriptio personae. 
count. At various times defendant did repurchase a portion of the securities; finally, however, it refused to perform its agreement. Complainant then instituted a suit for specific performance of the agreement, joining as defendants the bank, a receiver appointed for it, and a successor bank to which all the assets of the old bank had been assigned for purposes of liquidation. The lower court held the repurchase agreements were enforceable against the vendor bank alone, 4 and both complainant and defendant appealed. Two main problems ${ }^{5}$ were thus presented to the Illinois Supreme Court: (I) Were the agreements enforceable against the vendor bank? (2) If the vendor bank was liable on the agreements, is the successor bank also liable? The Court based its decision almost wholly on its solution to the first problem, holding the agreements ultra vires and unenforceable against the old bank, and thus unenforceable against the new bank.

By statute in Illinois banking institutions may be created "for the purpose of discount and deposit, buying and selling exchange and doing a general banking business . . . . and such banks or banking associations shall have the power to loan money on personal and real estate security and accept and execute trusts." As a bank incorporated under legislative sanction has only those powers expressly granted or necessarily implied from the statute under which it is created, ${ }^{7}$ the capacity of defendant bank to enter into repurchase agreements must be justified by reference to the terms of this general statute. The Supreme Court held that a promise to repurchase securities was not within the powers enumerated by the statute, and that there was no showing that such promises were part of any general banking practices. Thus the contract to repurchase was ultra vires.

But determination that a contract is ultra vires does not per se preclude its enforcement; in many cases the corporate promisor may be estopped to deny its lack of capacity. ${ }^{8}$ The Illinois court also found that the promises

4 Knass v. Madison \& Kedzie State Bank, 269 Ill. App. 588 (I933), noted in I Univ. Chi. L. Rev. 343 (r933).

$s$ A subsidiary problem also presented was as to whether defendant bank had actually signed the agreements, inasmuch as only the signature of one of its vice-presidents appeared on the face of the bills of sale (see supra note 3 ). The court might have held that the agreements were the personal obligation of the vice-president who signed, and not of defendant bank. See Mead v. Altgeld, I36 Ill. 298, 26 N.E. 388 (r8gr); Kinser v. Cal. Fire Clay Co., 165 Ill. 505, 46 N.E. 372 (1897); Braun v. Hess, 187 Ill. 283, 58 N.E. 37 I (rgo0); Murray v. Standard Pecan Co., 309 Ill. 226, 140 N.E. 834 (1923); 4 Michie, Banks and Banking (Perm. ed. r93I), \$\$ 7, 43.

'Ill. Cahill's Rev. Stat. (I933), c. $x 6 \mathrm{a}, \S$ I.

7 Ballantine, Corporations (I927), § 53; 4 Michie, Banks and Banking (Perm. ed. r93x), § I.

${ }^{8}$ Logan Co. Nat. Bank v. Townsend, I39 U.S. 67, Ir Sup. Ct. 496, 35 L. Ed. I07 (I89r); Aldrich v. Chemical Nat. Bank, x76 U.S. 618, 20 Sup. Ct. 498, 44 L. Ed. 6 II (I900); Citizen's Central Nat. Bank. v. Appleton, 216 U.S. r96, 3o Sup. Ct. 364, 54 L. Ed. 443 (19ro); Rankin v. Emigh, 218 U.S. 27, 30 Sup. Ct. 672, 54 L. Ed. 9r 5 (rgro); Farmers' and Merchants' Nat. . Bank v. Smith, 77 Fed. I29 (C.C.A. 8th 1896); Jackman v. Continental Nat. Bank, I6 F. (2d) 728 (C.C.A. 8th 1926); Coon v. Smith, 4 F. Supp. 960 (D.C.E.D. Ill. 1933). 
were contrary to public policy, as expressed in the Act of June 4,1879 , Section $4:^{9}$

"It shall not be lawful for any . . . incorporated bank receiving savings deposits, or deposits of trust funds, to assume the payment of, or to become liable for, or to guarantee to pay the principal of, or the interest on, any bonds, notes or other evidences of indebtedness of, for, or on account of any person or persons, company or incorporation; and in any assumption, liability or guarantee, whereby such deposits or trust funds could be jeopardized or impaired shall be null and void."

The court felt that the promises to repurchase were included within the language of this statute, regarding the vendor bank as a broker selling securities on commission for a mortgagor. It appears from the record in related cases, ${ }^{10}$ however, that the bank bought the securities at a discount and sold them at retail, retaining the profits; such securities as were not sold were placed in the investment portfolio of the bank. It seems somewhat difficult to bring a repurchase agreement within the exact language of the statute, because no liability is assumed on behalf of a third person; the bank merely contracted, on its own behalf, to provide a ready market for such securities as its customers desired to sell.

It would seem, however, that the statute does express a strong public policy against repurchase agreements. The dominant purpose of the statute was to protect depositors in savings banks by preventing such banks from embarking on speculative enterprises. A bank's promise to repurchase securities creates a liability which is contingent on circumstances over which the bank has little, if any, control. It is a liability which may force a bank to absorb large losses in the event of a market collapse, and thus result in paying out all of the bank's liquid assets, to the detriment of the depositors. The result reached by the court seems just, in view of the fact that the complainant may still sue the mortgagor, and may foreclose on the mortgaged property. On the other hand the depositor, who stands to gain nothing from the repurchase transaction (since the bank has no option to repurchase if the market value of the securities becomes higher than their par value), must rely on the general assets of the bank, which should not be jeopardized by the bank's speculation. The Federal Se-

9 Ill. Cahill's Rev. Stat. (I933), c. $38, \S 4$ I. The Illinois Constitution (1870), Art. XI, $\S 5$, provides that acts of the General Assembly creating corporations with banking powers must be ratified by popular vote, and this section was not submitted to popular vote. The court in the Knass case did not discuss the constitutionality of the section, however, probably relying on People v. Gould, 345 Ill. 288 , r 78 N.E. I33 (I93r), where it was held the constitutional provision was inapplicable because this section was a portion of the Criminal Code. On the other hand, it could be argued the section is not penal in nature, and thusthe fact that it appears in the Criminal Code is immaterial.

10 Freedman v. Madison \& Kedzie State Bank, 259 Ill. App. 5 I9 (r93I); Awotin v. Atlas .Exchange Nat. Bank, 265 Ill. App. 238 (1932); Knass v. Madison \& Kedzie State Bank, 269 Ill. App. 588 (I933); Hoffman v. Sears Community State Bank, 269 Ill. App. 644 (r933); cf. Madison \& Kedzie Trust \& Savings Bank v. Dean, 263 Ill. App. 646 (r931). 
curities Act, ${ }^{\mathrm{II}}$ the National Banking $\mathrm{Act},{ }^{12}$ and the Federal Deposit Insurance Corporation Act ${ }^{13}$ exemplify the growing public policy that security selling should be divorced from the banking business, and the $K$ nass case expresses a judicial realization of the same policy. Many bankers have also declared that security selling is not a proper commercial banking function. ${ }^{{ }^{4}}$

The complainant in the Knass case urged that the sale of the bonds and the agreement to repurchase constituted a conditional sale and so was not within the prohibitive legislation, citing Wolf $v$. National Bank of Illinois. ${ }^{15}$ In that case a vendor bank sought to avoid liability on a repurchase agreement on the theory that the agreement was void under the Illinois Gambling in Futures Act. $^{16}$ The court described the transaction as a conditional sale, mainly to prevent the application of the Gambling in Futures Act, which is unpopular and strictly construed. ${ }^{17}$ Subsequent cases overlooked a number of special facts in the Wolf case and construed all repurchase agreements as conditional sales. ${ }^{18}$ The court in the Knass case distinguished the Wolf case on its facts, but disregarded the cases subsequently misapplying it, and thus perhaps left the interpretation of repurchase contracts in some doubt. It seems clear, however, that the agreement in the $K$ nass case was not a conditional sale within the ordinary meaning of the term; the vendee complainant had exercised complete dominion over the securities, had sold some of them and hypothecated others, and was under no obligation to the bank in respect to them. ${ }^{\text {I9 }}$

THEODORE THAU

${ }^{11} 48$ Stat. 74 (1933), 5 U.S.C.A. Supp. $\$ \$ 77 \mathrm{a}-77 \mathrm{~mm}$ (1933).

${ }^{12} 48$ Stat. 184 (1933), I2 U.S.C.A. Supp. $\$ 24$ (1933).

${ }_{13}$ Part of the Banking Act of 1933,48 Stat. 168, I2 U.S.C.A. Supp. $\$ 264$ (r933).

14 Kraschel, State Banking Systems in Agricultural States, Great Lakes Banker (July 1933), 68; Holton, Strengthening Public Confidence in the Banks, Great Lakes Banker (July 1933), I9; Underhill, Real Estate, Pick and Choose, Am. Bankers' Assn. Jour. (Aug. 1933), 22; Weidenhammer, Control of New Investments, 17 I Annals Am. Acad. (Jan. I934), 73.

is 78 IIl. 85,52 N.E. 896 ( 1899 ).

I6 Ill. Cahill's Rev. Stat. (r933), c. $38, \S 308$.

${ }_{77}$ Ubben v. Binnian, 182 Ill. 508, 55 N.E. 552 (r899); Loeb v. Stern, rg8 Ill. 37 r, 64 N.E. I043 (I902); Miller v. Sincere, 273 Ill. I94, II2 N.E. 664 (IgI6); Stewart v. Dodson, 282 Ill. 192, I 18 N.E. 405 (rgr 7 ); r A.L.R. x544 (rgrg); 2 Williston, Sales (2d ed. x924), § 664.

${ }_{18}$ Ubben v. Binnian, 182 Ill. 508 , 55 N.E. 552 (I899); Stewart v. Dodson, 282 Ill. I92, I I8 N.E. $45_{5}$ (Igr 7); Roush v. Ill. Oil Co., I80 Ill. App. 346 (xgr3); Hills v. Hopp, 2 10 Ill. App. 365 (I918); Freedman v. Madison \& Kedzie Bank, 259 Ill. App. 519 (193I); Awotin v. Atlas Exchange Nat. Bank, 265 Ill. App. 238 (1932); Knass v. Madison \& Kedzie State Bank, 269 III. App. $5^{88}$ (1933); Hoffman v. Sears Community State Bank, 269 Ill. App. 644 (1933) cf. Coon v. Smith, 4 Fed. Supp. 960 (D.C.E.D. Ill. r933), decided before the Knass case changed the Illinois rule on repurchase agreements. Several other courts have construed repurchase agreements as conditional sales: Ophir Cons. Mines Co. v. Brynteson, I43 Fed. 829 (C.C.A. 7 th 1906 ); Hunt v. Wyman, I00 Mass. I98 (r868); Vent v. Duluth Coffee \& Spice Co., 64 Minn. 307,67 N.W. 70 ( 1896 ).

19 See Uniform Conditional Sales Act, $2 a$ U.L.A. (I924), § I; I Williston, Sales (2d ed. 1924), $\$ \$ 270-272$. 